\title{
Erratum to: Z-disc Transcriptional Coupling, Sarcomeroptosis and Mechanoptosis
}

\author{
Ralph Knöll · Byambajav Buyandelger
}

Published online: 16 May 2013

(C) Springer Science+Business Media New York 2013

Erratum to: Cell Biochem Biophys (2013) 66:65-71

DOI 10.1007/s12013-012-9430-6

Unfortunately the word "Mechanoptosis" in the title of the article was wrongly displayed as "Mechanopoptosis" in original publication. The corrected title of the article is: "Z-disc Transcriptional Coupling, Sarcomeroptosis and Mechanoptosis".

The online version of the original article can be found under doi: $10.1007 / \mathrm{s} 12013-012-9430-6$.

R. Knöll $(\square) \cdot$ B. Buyandelger

Myocardial Genetics, British Heart Foundation-Centre of

Research Excellence, National Heart \& Lung Institute, Imperial

College, Hammersmith Campus, London, UK

e-mail: r.knoell@imperial.ac.uk 